\title{
Safe water supply in emergencies and the need for an exit strategy to sustain health gains: lessons learned from the 2005 earthquake in Pakistan
}

\author{
M. Magan, ${ }^{7}$ K.M. Bile, ${ }^{7}$ B.M. Kazi²and Z. Gardezi ${ }^{3}$
}

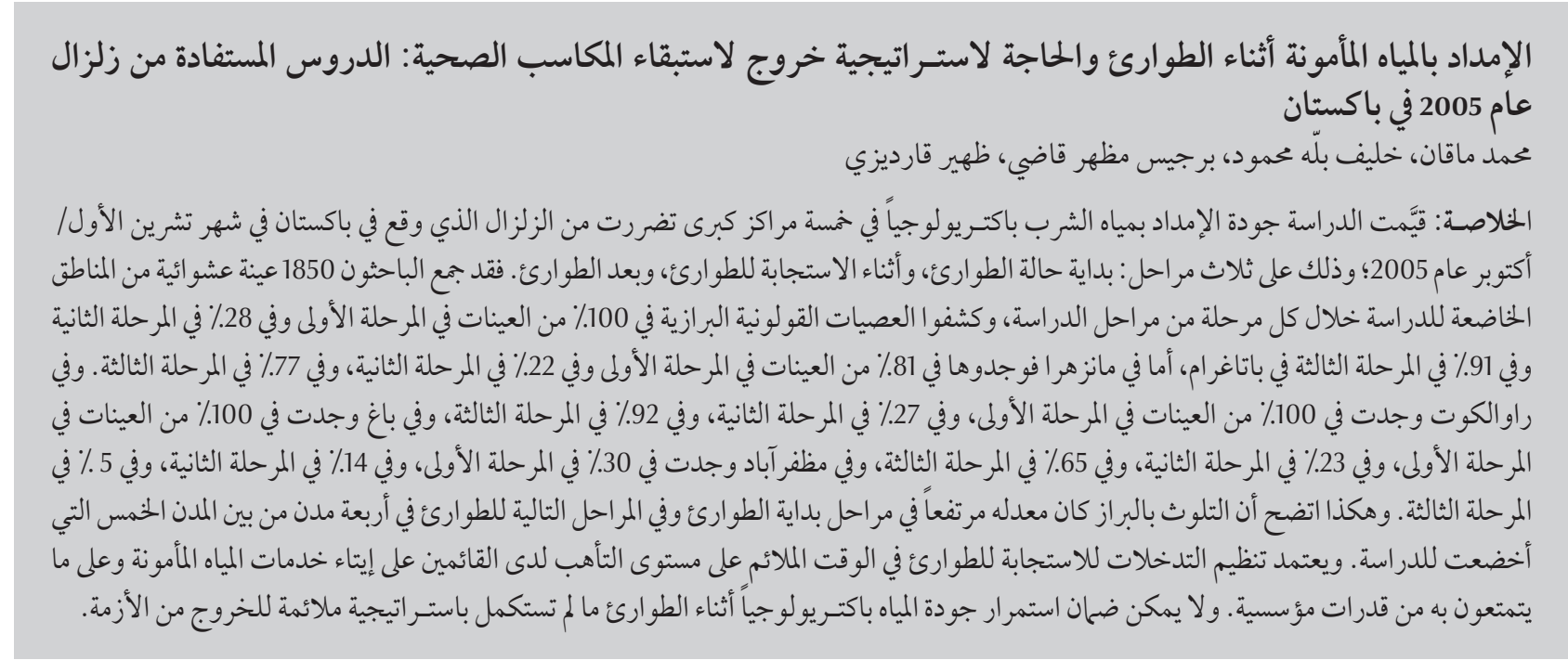

ABSTRACT The bacteriological quality of drinking-water supply of five major urban centres affected by the October 2005 earthquake in Pakistan were assessed in three phases: onset of emergency, during emergency response and post-emergency. A total of 1850 samples were randomly collected from the study area during each phase, and faecal coliforms were detected in 100\%, 28\% and 91\% in Battagram, 81\%, 22\% and 77\% in Mansehra, 100\%, 27\% and $92 \%$ in Rawalakot, $100 \%, 23 \%$ and $65 \%$ in Bagh and in 30\%, 14\% and 5\% in Muzaffarabad respectively. Faecal contamination was high during the onset of emergency and post-emergency phases in four out of the five surveyed towns. The organization of a timely emergency response intervention depends on the level of preparedness of local water-supply service providers as well as on their institutional capacities. Bacteriological water-quality improvements in emergencies may not be sustained unless complemented by a proper exit strategy.

\begin{abstract}
Approvisionnement en eau saine lors des situations d'urgence et nécessité d'une stratégie de sortie pour conserver les gains de santé : enseignements du tremblement de terre survenu en 2005 au Pakistan

RÉSUMÉ La qualité bactériologique de l'approvisionnement en eau de boisson dans cinq grands centres urbains touchés par le tremblement de terre d'octobre 2005 au Pakistan, a été évaluée au cours de trois phases : apparition de la situation d'urgence, riposte à la situation d'urgence et phase post-urgence. Au total, 1850 échantillons ont été prélevés au hasard dans la zone d'étude au cours de chaque phase. Le pourcentage d'échantillons de chaque phase contenant des coliformes fécaux s'établissait comme suit : $100 \%$, $28 \%$ and $91 \%$ à Battagram, $81 \%, 22 \%$ et $77 \%$ à Mansehra, $100 \%, 27 \%$ et $92 \%$ à Rawalakot, $100 \%$, $23 \%$ et $65 \%$ à Bagh, et enfin $30 \%$, $14 \%$ et $5 \%$ à Muzaffarabad. On a constaté une contamination fécale élevée au cours des phases d'apparition de la situation d'urgence et post-urgence dans quatre des cinq villes étudiées. L'organisation d'une intervention de riposte opportune à la situation d'urgence dépend du niveau de préparation des fournisseurs locaux en eau et de leurs capacités institutionnelles. L'amélioration de la qualité bactériologique de l'eau lors des situations d'urgence peut être compromise si elle n'est pas complétée par une stratégie de sortie adaptée.
\end{abstract}




\section{Introduction}

The associations between water, sanitation and health are well known, but these associations achieve greater importance following a natural or man-made disaster, when waterborne disease outbreaks may spread easily. Under such situations, adequate water supply and sanitation are essential for the health and well-being of affected communities. Diarrhoeal diseases are a major cause of morbidity and mortality among populations affected by emergencies, mostly, caused by unsafe drinking-water [1]. Consumption of water contaminated by faecal matter is one of the major causes of death in emergencies: for example, after the influx of 800000 Rwandan refugees into the Democratic Republic of the Congo in 1994, 85\% of the 50000 deaths recorded in the first month were caused by diarrhoeal diseases resulting mainly from bacteriologically contaminated water [2]. A compelling reason to promote improvement of bacteriological quality of water is the ability of this health-related intervention to reduce the infectious disease burden of the user population [3]. Microbial contaminants of drinking-water are of a higher priority than chemical contaminants, because their adverse health effects are usually immediate and more prevalent [4].

The 2005 earthquake in Pakistan affected a large population, a significant proportion of whom were living without access to safe water and proper sanitation even prior to the disaster. This situation was compounded by the devastating earthquake where 3880 water-supply schemes were damaged and needed rehabilitation and reconstruction [5]. The five densely populated urban centres of Rawalakot, Bagh, Muzaffarabad, Manshera and Battagram, which also hosted a large number of internally displaced persons in the aftermath of the earthquake, faced high risk of infectious disease outbreaks, which prompted the establishment of bacteriological water-quality monitoring and disease surveillance hubs in these affected towns. In each of these towns, the drinking-water supply was obtained from surface water sources or shallow springs that were easily contaminated by the disposal of untreated municipal wastewaters and drainage effluent from agricultural areas [6,7]. Earlier reports showed that surface water was faecally contaminated and required elaborate treatment for human consumption [8]. To improve bacteriological water quality, various types of water treatment system had been installed, but with the exception of those in Muzaffarabad town, they never worked properly due to poor management and lack of maintenance funds.

Prior studies have shown also that even fully protected sources and well managed systems do not guarantee that safe water is delivered to households as water collected from safe sources is likely to become contaminated during transportation and storage [9].

The aim of this study is to evaluate the bacteriological quality of drinkingwater supply during emergency and post-emergency periods, assess its effects on the frequency of acute diarrhoea and advocate the formulation of proper exit strategies that sustainably improve the drinking-water's bacteriological quality.

\section{Methods}

The study was conducted in five major urban centres of areas of Pakistan affected by the October 2005 earthquake from October 2005 till January 2010. Bacteriological water-quality data were collected in three phases: in the immediate aftermath of the disaster, from 10 October to 30 November 2005, when treatment systems were not fully in operation (phase 1); during emergency relief operations, 1 December 2005 to 30 May 2006, when the national and international emergency response was in full swing (phase 2); and during the post-emergency period, 1 June 2006 to 30 January 2010, when emergency support interventions were phased out (phase 3).

Bacteriological water-quality data collected in the three phases were compiled and analysed, while observations were made of the capacity of local authorities to sustain the attained improvements after scaling down the humanitarian support. Municipalities and water authorities where support was provided during the emergency period were revisited during the study in order to determine the level of safe water-supply services after the departure of the aid agencies and local emergency response teams. To get representative samples for the water-supply chain as a whole, water samples were obtained from the exit of the treatment plants, water storage tanks, various randomly selected water distribution lines, household water containers and from places most vulnerable to contamination. Water sampling was performed daily during the early stages of the emergency, but reduced later to weekly and monthly sampling depending on population size and overall risk of water contamination.

First the survey team conducted desk analysis for identification of water sources, water treatment plants, locations of storage tanks and layout of the distribution networks. To examine the bacteriological quality of drinking-water, survey teams measured water $\mathrm{pH}$, turbidity, residual chlorine and faecal coliform levels during the survey period. The detection of faecal coliforms in 100 $\mathrm{ml}$ of water sample was taken as an indicator of bacteriological contamination of drinking-water supplies.

The sample size, collection, preservations and analysis were conducted according to the standard methods for bacteriological water-quality testing [10], and proper procedures and precautionary measures were followed while collecting samples from the field. During sample collection, sanitary surveys were conducted on the sample 
collection sites' general cleanliness and possible sources of contamination. Water samples for microbiological contamination were collected in clean, sterile plastic bottles $(200 \mathrm{ml})$ and 1000 $\mathrm{ml}$ sterilized glass bottles; and care was taken to ensure that no accidental contamination occurred during sampling. Aseptic techniques were followed when handling the sterile sample bottles used for microbiological sample collection. The water samples for bacteriological quality were analysed for faecal coliform contamination only. Training was conducted for local drinking-water service providers on methods of conducting sanitary surveys, water sampling and physical and microbiological testing of water samples.

During the first seven months of the emergency period bacteriological water-quality testing was carried out using the $\mathrm{H} 2 \mathrm{~S}$ test kit, which has a high level of specificity and an acceptable level of enhanced sensitivity [9]. The Oxfam DelAgua water testing kit applying the membrane filtration method for detecting faecal coliforms was used during the remaining period of the study.

For $\mathrm{H} 2 \mathrm{~S}$ water testing, sample bottles were first sterilized with $6 \%$ bleach solution and then rinsed several times with the sample water before collecting the sample. A medium was then added, and the sample incubated at $25-35^{\circ} \mathrm{C}$ for 24 hours. If no black precipitate (a sign of test positivity) became apparent after 24 hours, it was incubated for another 24 hours. If the sample still remained clear yellow, a negative test result was recorded. Portable kits were used also for testing water $\mathrm{pH}$, turbidity and residual chlorine levels.

During the post-emergency phase (June 2006 to January 2010) the membrane filtration method was applied to estimate microbial quality of drinkingwater by using the Oxfam DelAgua water testing kit for detection of faecal coliforms [11]. A measured volume of water was filtered, under vacuum, through a cellulose acetate membrane of uniform pore diameter, $0.45 \mu \mathrm{m}$. Bacteria if present are retained on the surface of the membrane, which is placed on a suitable selective medium in a sterile container and incubated at an appropriate temperature. If faecal or other coliforms are present in the water sample, characteristic colonies form that are counted directly. For treated water, $10 \mathrm{mg}$ of sodium thiosulfate per $100 \mathrm{ml}$ of chlorinated water was added to neutralize chlorine in the sample before undertaking microbial testing.

The reported incidence data of acute diarrhoea, compiled for over a period of four years were obtained from the disease early warning system (a communicable disease surveillance system designed to detect epidemics and guide timely response strategies) and analysed using EPI-Info software.

\section{Results}

This study was conducted in five major urban centres (Muzaffarabad, Bagh, Rawalakot, Mansehra and Battagram) affected by the 2005 earthquake, and water microbial quality was surveyed in three phases: in the immediate aftermath of the disaster; during emergency relief operations; and during the postemergency period.

During phase 1 some baseline data on the quality of the existing watersupply systems were obtained by the environmental health teams who were assisted by the World Health Organization (WHO). The same bacteriological water-quality parameters were tested during phase 2 and phase 3 of the study to determine any significant variation of the bacteriological quality of the drinking-water supplies. All surveyed towns received most of their drinking-water supplies from surface water sources that were susceptible to contamination, except Bagh, which received water from a spring source.

Results of the study revealed the poor microbial quality of most available water supplies during phase 1 and phase 3 of the study (Table 1). It also demonstrated how microbial quality of water deteriorated in between the source and consumer end. Phase 1 of the study detected faecal coliforms in $100 \%$ of the water samples obtained from various water sampling sites in Bagh, Rawalakot and Battagram (Table 1). With the exception of Muzaffarabad, water treatment plants in most of these urban centres had never functioned properly due to years of neglect and shortage of operational funds.

During phase 2 of the study, an extensive national and international response was mobilized, and effective measures taken to ensure the safety of drinking-water supplies by the government- and UNICEF-led Water, Sanitation and Hygiene (WASH) cluster. Dysfunctional water treatment systems in Battagram, Mansehra, Rawalakot and Bagh were immediately rehabilitated, and proper water treatment/disinfection systems introduced. This resulted in a tremendous improvement in the microbial quality of the drinking-water, where faecal coliforms were detected in only $23 \%$ of samples in Bagh, $27 \%$ in Rawalakot and 28\% in Battagram (Table 1).

After May 2006, during phase 3 of the study, when the humanitarian situation of the affected areas was stabilized, most international and national aid agencies scaled down their operations in the field and consequently the support for bacteriological water-quality improvements dwindled substantially. Water treatment systems of four out of the five surveyed towns could not be maintained by the local authorities due to lack of sufficient funds. It was frequently observed that most water treatment plants lacked sufficient water treatment chemicals (alum and chlorine).

It was also observed that water microbial quality deteriorated in between the source and the consumer due to intermittent supply, cross-connections 
with sewerage systems and unhygienic handling of water at household level. Sanitary surveys conducted in the urban centres revealed that many sections of drinking-water distribution pipes were installed inside open wastewater channels that were full of stagnant wastewater (Figure 1). Results showed that although Muzaffarabad drinking-water supply was safe at the exit point of the treatment plant, faecal contamination was detected during all phases of the study at the household level, with the presence of faecal coliforms in $60 \%$, $25 \%$ and $9 \%$ of water samples respectively (Table 1).

Phase 1 results revealed also that residual chlorine was detected in only one of the five surveyed towns' watersupply systems (Table 2); 60\% of Muzaffarabad water samples were found to have residual chlorine levels matching WHO guide range of values [12]. Water turbidity occasionally exceeded WHO guide values during the rainy season; however all water samples were

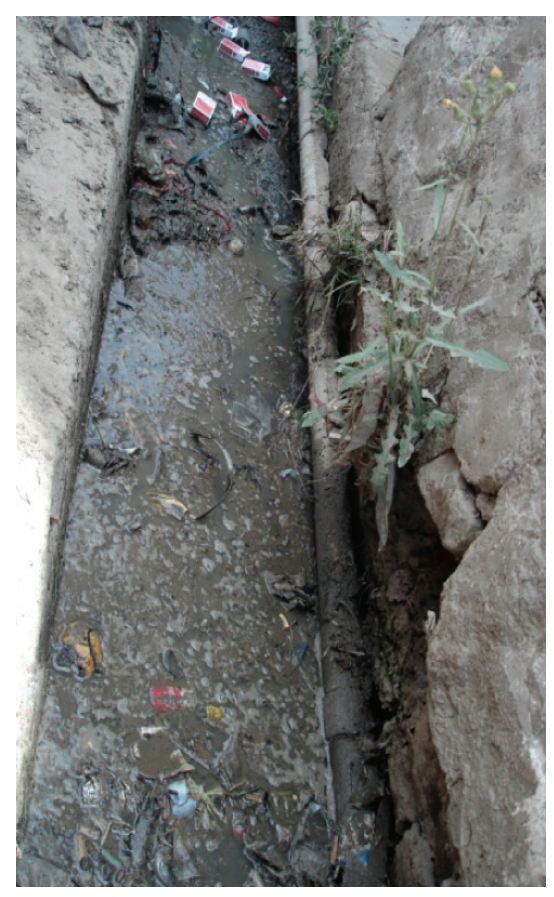

Figure 1 Typical practice of installing drinking-water delivery pipes inside open waste and storm water channels found to be within WHO $\mathrm{pH}$ guide values (6.5-8.5).

Figure 2 illustrates a four-year monthly trend of acute diarrhoea of the five major towns affected by the 2005 earthquake. The frequency of acute diarrhoea during the monsoon period was significantly lower in Muzaffarabad relative to the other four towns with an odds ratio ranging from 2.81 to 12.72 and with $95 \%$ confidence interval of 2.74 to 13.03 .

The dissemination of the results was usually shared with various stakeholders through Water, Sanitation and Hygiene (WASH) cluster meetings in order to adopt preventive measures and create awareness amongst the population and local authorities.

After the emergency phase and the scaling down of the aid agencies' support, the water and sanitation section of Pakistan's Earthquake Rehabilitation and Reconstruction Authority (ERRA) and WHO put their emphasis on building capacity of local service providers through structured multilevel training activities in order to raise awareness among all stakeholders on the interlinkages between safe water and health. To make capacity-building interventions more practical, basic bacteriological water-quality testing equipment was provided to various local water authorities.

To strengthen routine bacteriological water-quality monitoring, WHO supported the establishment of nine bacteriological water-quality testing laboratories in nine districts of the affected areas, where in addition 18 water-laboratory technicians received bacteriological water-quality testing and monitoring refresher training courses.

ERRA's water and sanitation section and WHO held several workshops and meetings with provincial authorities where the results and conclusions of the WHO-supported bacteriological water-quality survey were presented to all stakeholders.
ERRA's water and sanitation section, UNICEF and water-supply service providers jointly launched a comprehensive bacteriological water-quality improvementand promotion of hygiene project in February 2009. Under this project, sanitary inspection surveys of over 3500 water-supply schemes will be carried out.

\section{Discussion}

At the onset of an emergency, a major strategic objective is to protect the health and well-being of the affected population by focusing primarily on the provision of essential health services, safe drinking-water, food and shelter [1]. WHO assigned high priority to the provision of safe water and proper sanitation as an integral component of the health response, complementing disease surveillance and epidemic control interventions.

Phase 1 bacteriological water-quality surveys revealed the poor microbial quality of most available drinking-water supplies mainly due to lack of preparedness, corroborated by prior studies carried out by the Pakistan Council of Research on Water Resources [13]. It is worth emphasizing that preparedness is essential for dealing with emergency safe drinking-water supply, especially the predeployment and stockpiling of sufficient quantities of water treatment chemicals and storage containers. Emergency preparedness and response programmes can be used as an essential link between emergency relief, rehabilitation/reconstructionand development requiring institutional capacity-building and awareness promotion at the community level to reduce vulnerability and the risks of waterborne diseases [14].

Surface water represented the most accessible supply of water to the affected communities, but these sources were easily contaminated by pathogenic organisms and could not be considered safe without treatment $[15,16]$. The 
응

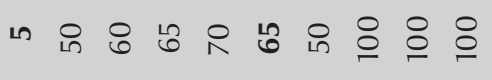

สู

$N \wedge \stackrel{\infty}{\infty} \cong$

5

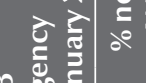

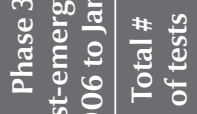

ㅇㅅ

窇

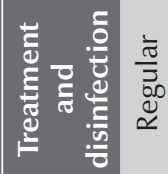

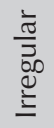

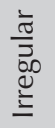

$\frac{\bar{t}}{\frac{1}{20}}$

స్휴

๑ั

匀

士ం○임

ลิ 0 ㅇำ

商

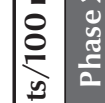

装

ฯ 2 เ $\infty$

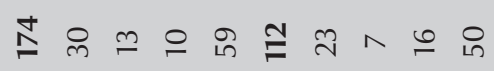

ดำ $=$ ำ

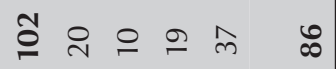

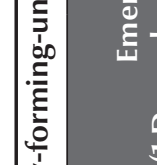

总

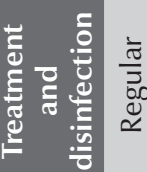

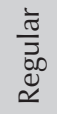

$\frac{\bar{\pi}}{\sqrt{2}}$

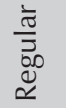

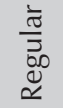

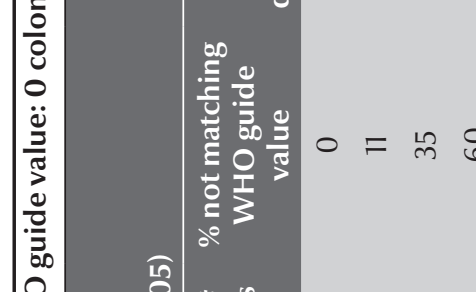

용ㅇㅇㅇ

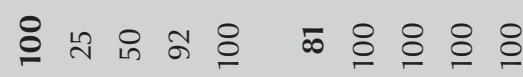

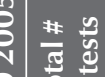

$m \wedge+$

\& $m+n \pm$ 迎n

h +407

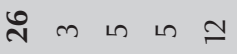
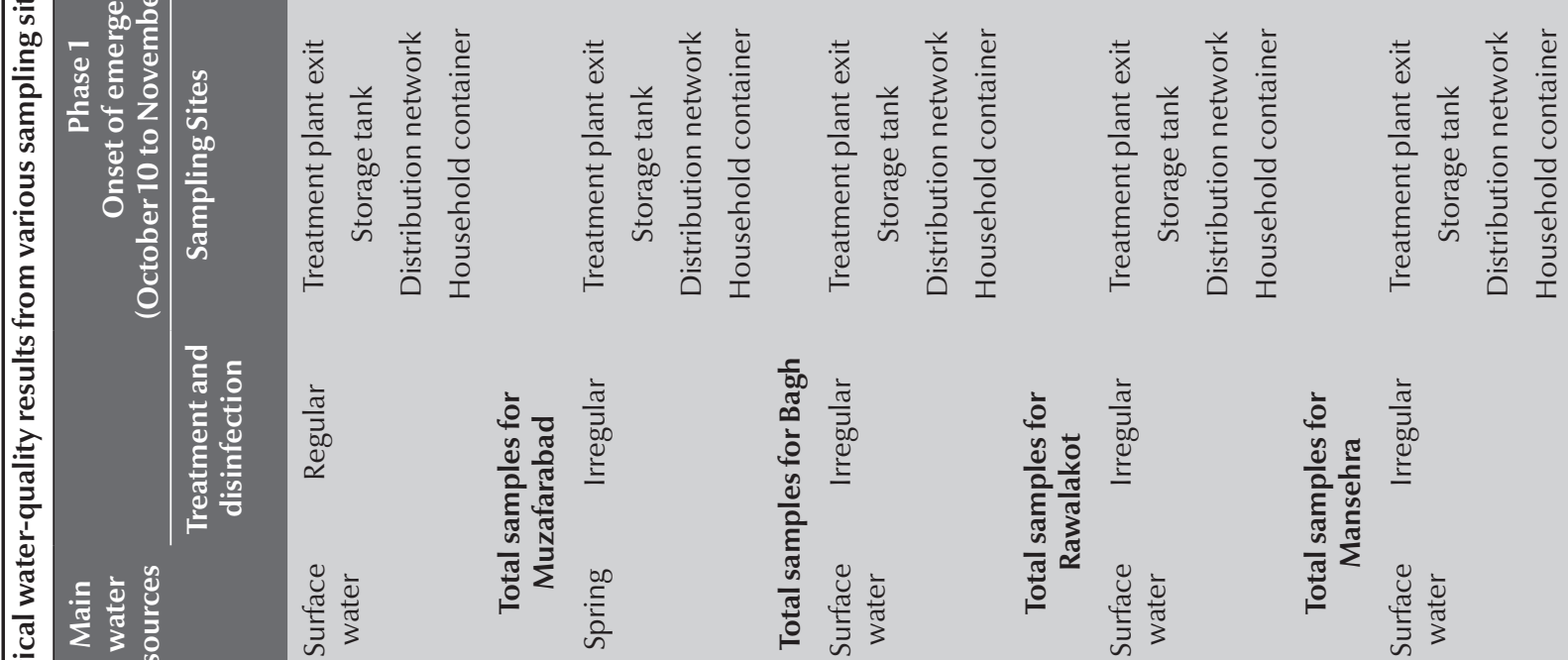

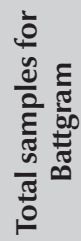

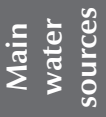

总离

言

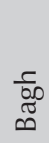

$\frac{\sqrt{\pi}}{\frac{\pi}{\frac{\pi}{0}}}$

$\frac{\pi}{2}$
$\frac{\pi}{0}$
$\frac{n}{\pi}$
$\sum$

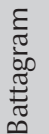




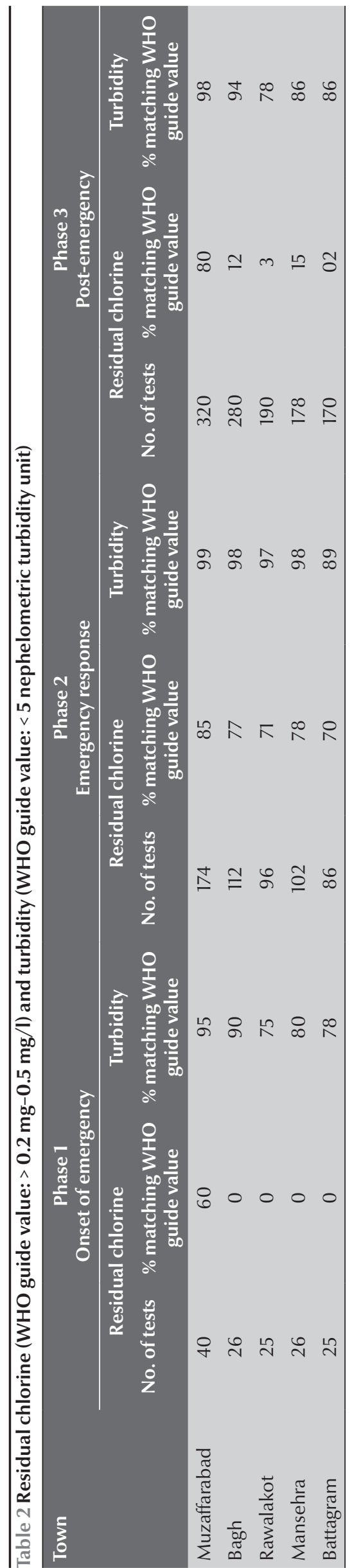

costs and sustainability issues associated with surface water treatment, particularly routine maintenance of water treatment plants, need to be carefully considered before surface water sources can be exploited [17].

A remarkable improvement of water safety was attained during phase 2 of the study, when the concern over a second wave of deaths from communicable diseases resulted in massive local and international support to ensure the provision of safe water supplies to all affected communities. These efforts led to a considerable improvement in the microbial quality of water, with residual chlorine levels measured in most drinking-water supply systems matching WHO guide values. However, the Battagram surface water treatment system always faced difficulties, due to its incomplete water treatment infrastructure.

The contribution of safe water supply and proper sanitation to health must always be recognized as a priority area during emergencies and post-emergency reconstruction and development phases for which the necessary resources are to be mobilized.

During phase 3 of the study, when most international and national humanitarian support agencies scaled down their operations in the field, the support for bacteriological waterquality improvements to various affected districts dwindled substantially. Results indicated the dramatic decline of the bacteriological quality of most available drinking-water supplies in four out of the five towns surveyed.

Results in all three phases of the study revealed also that water microbial quality deteriorated in between the source and the consumer end, reaffirming earlier findings that even fully protected sources and well managed systems do not guarantee that safe water is delivered to households [2]. Safe sources are important, but it is only with improved hygiene, better water storage and handling and improved sanitation that the quality of water consumed by people can be assured. Extending bacteriological water-quality protection from the sources to point of use is increasingly becoming a common strategy in water-safety programmes worldwide [2].

The relationship between the frequency of diarrhoea diseases and the bacteriological quality of drinking-water was substantiated by the

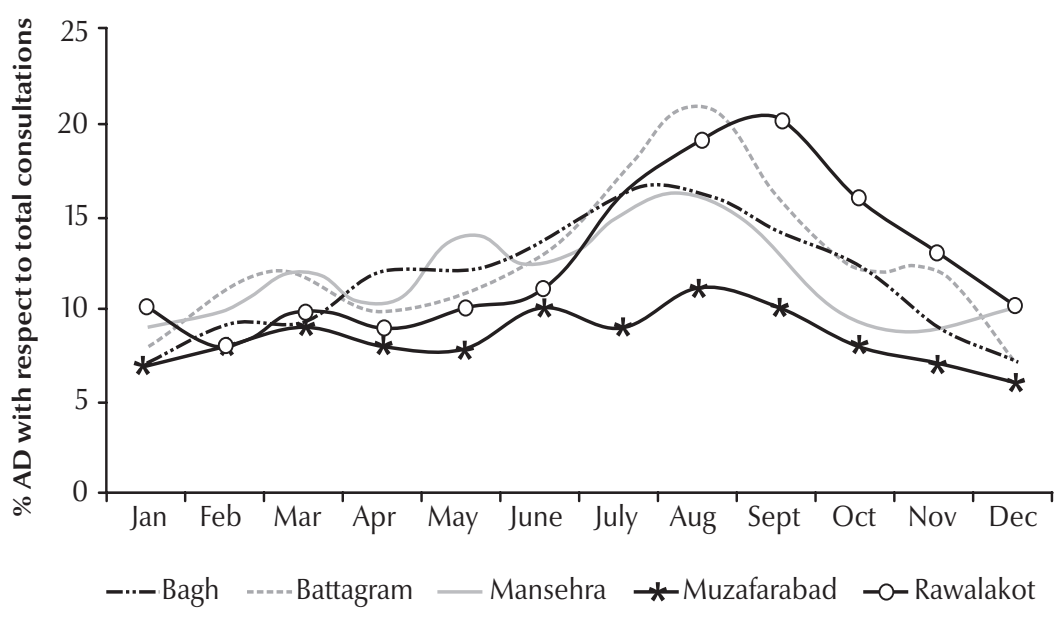

Figure 2 Average monthly pattern of acute diarrhoea (AD) in five major towns affected by the 2005 earthquake in Pakistan during 2006-09 
evident inverse correlation between the frequency of acute diarrhoea and bacteriological water quality: there was a statistically significant diarrhoea risk variance between Muzaffarabad and the other towns surveyed. The latter illustrates that excess morbidity and mortality caused by diarrhoeal diseases are largely avoidable if bacteriological contamination of water is effectively controlled [12].

The necessary capacities of local water-supply service providers need to be built to guarantee a sustainable exit strategy after the emergency response aid organizations cease their support. To address this challenge, humanitarian organizations and the government need to establish the necessary operational steps during the early recovery phase of the emergency response in order to meet the necessary technical, managerial and funding requirements to maintain the quality of water-supply systems. The latter illustrates the necessity of formulating sustainable exit strategies during the emergency response phase, recognizing the responsibility of the local authorities to maintain the provision of safe drinking-water to the population [18]. To address the water-safety issues in the long run it is vital to sensitize all the stakeholders in such a way that water-supply service providers and consumers are fully aware of the linkages between safe water and health. The post-earthquake experience has shown the predominant focus of humanitarian partners on short-term water safety solutions rather than developing sustainable exit strategies that can build local capacities. The human resource and institutional capacity-development efforts undertaken by the government, assisted by WHO and UNICEF, could not produce the desired results due to paucity of recurrent financing, a matter that needs utmost priority attention.

\section{Conclusion}

Emergency health and WASH response interventions aim to promote earliest possible actions to reduce any loss of life in the aftermath of disasters. This adversity however needs to be seen as an opportunity to build-back-better and develop the capacity of local institutions in order to attain a reliable level of water safety and pursue it as an integral part of the exit strategies that render the humanitarian response gains more sustainable.

\section{References}

1. Connolly MA ed. Communicable diseases control in emergencies: a field manual. Geneva, World Health Organization, 2005:33.

2. Connolly MA et al. Communicable diseases in complex emergencies: impact and challenges. Lancet, 2004; 364(9449):842843.

3. Sobsey MD. Managing water in the home: accelerated health gains from improved water supply water. Geneva, World Health Organization, 2002 (WHO/SDE/WSH/02.07; http://www. who.int/water_sanitation_health/dwq/wsh0207/en/print. $\mathrm{html}$, accessed 19 July 2010).

4. Thompson T et al. Chemical safety of drinking water: assessing priorities for risk management. Geneva, WHO, 2007.

5. Water and sanitation strategy July 2006-June 2009: Build back better. Islamabad, Pakistan, Earthquake Reconstruction and Rehabilitation Authority, 2006 (http://www.erra.pk/Reports/ Watsan-Strategy/WatSan-Strategy8sep.pdf, accessed 19 July 2010).

6. Kahlown MA, Tahir MA, Rasheed H. Fifth water quality monitoring report 2005-2006. Islamabad, Pakistan, Pakistan Council of Research in Water Resources, 2008.

7. Aziz JA. Management of source and drinking water quality in Pakistan. Eastern Mediterranean Health Journal, 2005 11(5-6):1087-1098.

8. Nasrullah et al. Pollution load in industrial effluent and groundwater of Gadoon Amazai industrial estate (GAIE) Swabi, NWFP. Journal of Agricultural and Biological Science, 2006, 1(3):1824 (http://www.arpnjournals.com/jabs/research_papers/ jabs_0906_23.pdf, accessed 20 July 2010).

9. UNICEF handbook on water quality 2008. New York, USA, United Nations Children's Fund, 2008

10. Standard methods for the examination of water and wastewater. Denver, USA, American Public Health Association/American
Water Works Association/Water Environment Federation, 2000.

11. DelAgua portable water testing kit. User manual. Marlborough, United Kingdom, DelAgua Water Testing Ltd, 2000.

12. Guidelines for drinking-water quality 1, 3rd ed. Geneva, World Health Organization, 2008 (http://www.who.int/water_sanitation_health/dwq/gdwq3rev/en/index.html, accessed 20 July 2010).

13. Kahlown MA, Tahir MA, Rasheed H. Water quality status in Pakistan (third report 2003-2004). Islamabad, Pakistan, Pakistan Council of Research in Water Resources, 2005 (No. 131-2005).

14. Policy: integrating relief, rehabilitation and development 2006. Geneva, International Federation of Red Cross and Red Crescent Societies, Disaster Preparedness and Response Department, 2006.

15. Schmoll O et al, eds. Protecting groundwater for health. Managing the quality of drinking-water sources. Geneva, World Health Organization, 2006 (http://www.who.int/water_sanitation health/publications/protecting_groundwater/en/index.html, accessed 20 July 2010 ).

16. Hubbs SA. Understanding water supply and treatment for individual and small community systems. Arlington, USA, Volunteers in Technical Assistance, 1985 (Technical Paper 32; http://www. cd3wd.com/cd3wd_40/vita/wtrtreat/en/wtrtreat.htm, accessed 20 July 2010).

17. Guidelines on technologies for water supply systems in small communities. Amman, WHO Regional Centre for Environmental Health Activities, 1993.

18. Water and sanitation policy. Geneva, International Federation of Red Cross and Red Crescent Societies, 2003 (http://www. ifrc.org/Docs/pubs/who/policies/watsan-policy-en.pdf, accessed 20 July 2010). 